\title{
Ovine White-Liver Disease (OWLD). Pathology
}

\author{
By Martha J. Ulvund
}

State Veterinary Research Station for Small Ruminants, Høyland, Sandnes, Norway.

\begin{abstract}
Ulvund M.J.: Ovine white-liver disease (OWLD). Pathology. Acta vet. scand. 1990, 31, 309-324. - Microscopic liver changes could earliest be found after 1 month on OWLD pasture, and included extensive fatty change with large spherical vacuoles in hepatocytes, varying size of hepatocytes and nuclei, and formation of Councilman bodies. Later came ceroid deposits, biliary hyperplasia and mesenchymal proliferation. Changes occurred in all lambs which died or were killed due to OWLD, and altogether $83 \%$ of the lambs grazing OWLD pastures showed typical or suspect changes. Widespread haemosiderosis of the spleen was common. In severely affected lambs, sclerosis of the Peyer's patches and of the germinative centres of the intestinal lymph nodes were seen, as were neuronal atrophy and patchy microcavitation of areas in the brain stem. Four had polyvasculitis.

Cobalt/vitamin $B_{12}$ supplemented lambs showed no specific changes. Lambs which grew well on other pastures ( $\mathrm{H}$ lambs), but which were subclinically $\mathrm{Co} / \mathrm{B}_{12}$ deficient some years, showed no fulminant hepatic OWLD, but $15 \%$ developed some features seen in OWLD. They showed no extensive fatty change.

Results indicate that OWLD is a manifestation of $B_{12}$ deficiency worsened by factors triggering early hepatic fatty change resulting in a more severe liver damage with loss of intracellular homeostasis rendering the hepatocytes vulnerable to other elements, like copper.
\end{abstract}

sheep; cobalt/vitamin $B_{12}$ deficiency.

\section{Introduction}

Ovine white-liver disease (OWLD) has been characterized by fatty change, hepatocyte necrosis, ceroid deposits and bile duct proliferation (Sutherland et al. 1979, Ulvund \& Øverás 1980). Status spongiosus of the brain (Richards \& Harrison 1981) and polioencephalomalacia (Sutherland et al. 1979) have been reported in some lambs.

It has been unclear whether OWLD is a pure cobalt/vitamin $B_{12}$ deficiency, or whether coexistent factors are necessary for development of the disease. Our experiments indicate that although $\mathrm{Co} / \mathrm{B}_{12}$ dificiency is essential, cofactors play a part (Ulvund $1990 \mathrm{~b}, \mathrm{~d}$, Ulvund \& Pestalozzi 1990b).
Pure Co deficiency results in fatty infiltration of the liver and deposition of haemosiderin in the spleen (Filmer 1933). In experimental Co deficiency, MacPherson et al. (1976) and Fell (1981) in fact found liver lesions similar to those seen in OWLD.

This article describes the pathology, especially the development of microscopic liver changes, in lambs with OWLD as compared with $\mathrm{Co} / \mathrm{B}_{12}$ supplemented lambs grazing the same pastures, and normally growing lambs on other pastures, some of which were subclinically $B_{12}$ deficient. 


\section{Materials and methods}

Experimental design has been described ( $\mathrm{Ul}$ vund \& Pestalozzi 1990a, Ulvund 1990c). Altogether 458 twin lambs of the Dala and Rygja breeds were included during a 6-year study (1981-86). Pasture outlet was in mid May each year, when the lambs were about 1 month old. The lambs grazed with their dams throughout the experimental period. Lambs designed $\mathrm{S}$ grazed OWLD pastures, which were either moderately (SCo) or heavily $(\mathrm{SCo}+)$ fertilized with $\mathrm{Co}$, or not Co fertilized (S). H lambs grazed disease free control pastures, which some years had marginal to deficient Co contents. Prophylactic measures and symbols used are given in Table 1.

Development of the lesions was especially scrutinized during one year (1982). Altogether 16 lambs from 3 groups were killed after 11 and 22 days, and later after 1, 2, 3 and 5 months respectively on pasture (Table 2 ). Necropsy was performed in these, and in additional 17 lambs which died or were killed by intravenous injection of pentobarbital throughout grazing (Table 3). Based on the development of the liver lesions, criteria for typical $(+)$ and suspect/indicative OWLD $( \pm)$ were put up.
In all 33 lambs which were necropsied (Table 3 ), liver ( 2 or 3 sections), ileum, spleen, jejunal lymph nodes, myocardium, lung and brain were examined. In the 16 lambs killed throughout grazing, following additional specimens were examined: Rumen, abomasum, duodenum, jejunum, caecum, colon, adrenals, kidney and muscles.

In addition, livers were examined from altogether 218 lambs from the various groups slaughtered at the end of the experimental period. Brains, ileum and jejunal lymph nodes were examined from altogether 39 lambs slaughtered in 1981, ileum and jejunal lymph nodes from 29 lambs slaughtered in 1983, and kidneys from 46 lambs slaughtered in 1985.

Tissues were fixed in $10 \%$ neutral buffered formalin (Carson et al. 1973) within a few minutes after killing, or about $1 \mathrm{~h}$ after slaughter. Tissues from the lambs found dead were fixed 1-18 $\mathrm{h}$ after death. Tissue samples were processed by conventional paraffin embedding, and routinely stained with haematoxylin eosin (HE). In 1982, additional stains were used for liver, spleen, lymph nodes and ileum: Periodic acid Schiff (PAS), van Gieson, Ziehl-Nielsen and Berlin (Culling 1963). Blood was drawn at killing

Table 1. Survey of group symbols used in the experiments.

\begin{tabular}{|c|c|}
\hline $\mathrm{S}$ & : Lambs grazing OWLD pastures \\
\hline $\mathrm{SCO}$ & : Lambs grazing moderately cobalt fertilized OWLD pastures \\
\hline $\mathrm{SCo}+$ & : Lambs grazing heavily cobalt fertilized OWLD pastures \\
\hline $\mathrm{SCoSO}_{4}$ & : Lambs dosed weekly with cobalt sulphate by mouth \\
\hline $\mathrm{SB}_{12}$ & : Lambs injected every two or three weeks with vitamin $B_{12}$ \\
\hline $\mathrm{SCuO}$ & : Lambs dosed with copper oxide needles \\
\hline SCopell & : Lambs dosed with cobalt pellets \\
\hline $\mathrm{SCoSeCu}$ & : Lambs dosed with cobalt-selenium-copper glass boli \\
\hline $\mathrm{SSe}$ & : Lambs dosed with selenium pellets \\
\hline SColick & : Lambs having access to cobalt salt lick on OWLD pasture \\
\hline $\mathrm{H}$ & $\begin{array}{l}\text { Lambs grazing disease-free } \mathrm{H} \text {-pastures situated elsewhere } \\
\text { Several } \mathrm{H} \text { lambs were subclinically } \mathrm{Co} / \mathrm{B}_{12} \text { deficient }\end{array}$ \\
\hline $\mathrm{HCo}$ & : Lambs grazing $\mathrm{Co}$ fertilized $\mathrm{H}$ pastures \\
\hline HCopell & : Lambs grazing $\mathrm{H}$ pastures, but dosed with cobalt pellets \\
\hline HColick & : Lambs having access to cobalt salt lick on $\mathrm{H}$ pasture \\
\hline
\end{tabular}


Table 2. Survey of lambs which were killed at various intervals throughout grazing, 1982. Time on pasture, lamb group and number, age (days) and live weight (lw, $\mathrm{kg}$ ) at killing date, mean lw for the group, and weight increase ( $\mathrm{g} /$ day) in each lamb during the 2 weeks preceeding killing. Serum glutamate dehydrogenase (GLDH, $\mathrm{U} / \mathrm{l})$, plasma methylmalonic acid $(\mathrm{MMa}, \mu \mathrm{mol} / \mathrm{l})$ and vitamin $\mathrm{B}_{12}(\mathrm{pmol} / \mathrm{l})$ on the date of killing are also given. For group symbols, see Table 1 .

\begin{tabular}{lllrllllrr}
\hline $\begin{array}{l}\text { Time on } \\
\text { pasture }\end{array}$ & Group & $\begin{array}{l}\text { Lamb } \\
\text { number }\end{array}$ & Age & Lw & $\begin{array}{l}\text { Mean } \\
\text { lw }\end{array}$ & g/day & GLDH & MMA & B $_{12}$ \\
\hline 11 days & $\mathrm{S}$ & 1 & 32 & 19 & 14 & 429 & 4 & 2 & 158 \\
$11-$ & $\mathrm{SB}_{12}$ & 2 & 35 & 13 & 15 & 214 & 11 & 1 & 1168 \\
$11-$ & $\mathrm{H}$ & 3 & 41 & 13 & 13 & 429 & 12 & 84 & 41 \\
22 days & $\mathrm{S}$ & 4 & 52 & 15 & 17 & 286 & 13 & 3 & 52 \\
$22-$ & $\mathrm{SB}_{12}$ & 5 & 59 & 21 & 17 & 286 & 14 & - & 3345 \\
$22-$ & $\mathrm{H}$ & 6 & 37 & 13 & 15 & 286 & 11 & 44 & 119 \\
1 month & $\mathrm{S}$ & 7 & 66 & 17 & 18 & 357 & 53 & 49 & 66 \\
$1-$ & $\mathrm{SB}$ & 8 & 45 & 19 & 19 & 429 & 6 & 2 & 402 \\
$1-$ & $\mathrm{H}$ & 9 & 49 & 16 & 18 & 286 & 13 & 3 & 322 \\
2 months & $\mathrm{S}$ & $10^{*}$ & 82 & 11 & 26 & $\div 71$ & 887 & 24 & 90 \\
$2-$ & $\mathrm{S}$ & 11 & 100 & 15 & 26 & $\div 143$ & 168 & 53 & - \\
& $\mathrm{SB}$ & 12 & 86 & 32 & 29 & 429 & 13 & 2 & - \\
3 months & $\mathrm{S}$ & 13 & 114 & 30 & 29 & 214 & 40 & 80 & 99 \\
3 & $\mathrm{~S}$ & 14 & 115 & 33 & 35 & 286 & 12 & 3 & 5540 \\
3 & $\mathrm{~S}$ & 15 & 120 & 41 & 41 & 429 & 8 & 3 & 143 \\
5 months & $\mathrm{S}$ & $16 *$ & 160 & 17 & 27 & $\div 143$ & 21 & 19 & 94 \\
\hline
\end{tabular}

* Killed because of severeness of the OWLD condition.

Table 3. Total number of lambs $(n=33)$ examined post mortem. Year of experiment, lamb group and number of weeks on pasture before dying (D) or killing (K) are given. For group symbols, see Table 1.

\begin{tabular}{lll}
\hline Year & Group & Weeks of pasture \\
\hline 1981 & $\mathrm{~S}$ & $\mathrm{D}: 2,9,15^{*}$ \\
& & $\mathrm{~K}: 18^{*}, 20^{*}, 21^{*}$ \\
& $\mathrm{SCoSO}_{4}$ & $\mathrm{D}: 13,21$ \\
1982 & $\mathrm{~S}$ & $\mathrm{~K}: 1.5-21$ (5 lambs) \\
& & $7^{*}, 20^{*}$ \\
& $\mathrm{SB}_{12}$ & $\mathrm{~K}: 1.5-21$ (5 lambs) \\
& $\mathrm{H}$ & $\mathrm{K}: 1.5-13$ (4 lambs) \\
1983 & $\mathrm{~S}$ & $\mathrm{D}: 6$ \\
& & $\mathrm{~K}: 20^{*}$ (4 lambs) \\
1984 & $\mathrm{~S}$ & $\mathrm{~K}: 19^{*}$ \\
& $\mathrm{SB} \mathrm{B}_{12}$ & $\mathrm{~K}: 19$ \\
& $\mathrm{SCuO}$ & $\mathrm{K}: 19^{*}$ (2 lambs) \\
\hline
\end{tabular}

* Lambs which died of OWLD, or were killed due to severeness of OWLD. and examined for vitamin $B_{12}$, methylmalonic acid (MMA), and glutamate dehydrogenase (GLDH, Ulvund 1990a, b).

\section{Results}

Altogether 11 out of 60 unsupplemented lambs grazing the OWLD pastures (S lambs) died or were killed due to OWLD (Table 3). Additional 2 lambs which grazed the same pastures, but which were dosed with copper (SCuO lambs), also had to be killed due to severeness of disease. One lamb dosed with cobalt sulphate $\left(\mathrm{SCoSO}_{4}\right)$ died of torsion of the gall bladder, while $1 \mathrm{SCoSO}_{4}$ lamb and 3 $\mathrm{S}$ lambs were found dead on pasture with signs of diarrhea (Table 3).

\section{Necropsy}

The lambs which were killed after 11 and 22 days on pasture (Table 2) were normal. The 
S lamb killed after 1 month had swollen, pale and soft liver only. The $\mathrm{S}$ lambs killed after 2, 3 and 5 months respectively had changes typical for OWLD, as reported below. No specific changes were found in the killed $\mathrm{B}_{12}$ supplemented lambs $\left(\mathrm{SB}_{12}\right)$ or the normally growing lambs grazing other pastures (H lambs).

All lambs which died or were killed due to OWLD were emaciated, had crusty ears, eye discharge, rough wool, and pale mucous membranes. The livers were pale, swollen and doughy with reduced texture, in some the surface had irregular raised paler areas (Fig. 1). Myocardium was soft, skeletal muscles appeared pale and poorly developed. The gastrointestinal organs had reduced size and fillness. The jejunal wall appeared thin, and the lymph nodes were moist and slightly swollen. A few lambs had moderate ascites.

Two OWLD lambs which died or were killed after 15 and 18 weeks on pasture (1981, Table 3) had numerous pin head sized yellowish foci in the liver, myocardium, kidney cortex and jejunal mucosa. One of them had visible thrombi in vessels of the mesenterium, intestinal wall, ovaries and ovarial ligaments.

The 2 SCuO lambs (Table 3) were icteric. Out of 48 livers from S lambs, 33 (69\%) were pale/soft or soft only (Table 4).

Development of microscopical liver changes After 11 and 22 days on pasture: All lambs had normal livers.

After 1 month: Lamb 7 (Table 2) had extensive centroacinar lipid accumulation shown as large distinct spherical vacuoles displacing the nucleus in the hepatocytes (Fig. 2\&3). The hepatocytes varied in size, there were scattered swollen cells with enlarged nuclei, swollen nucleoli, and hyperchromatosis of nuclear walls (anisocytosis/-nuc- leosis, Fig. 2C). Some swollen hepatocytes contained bright homogenous or foamy cytoplasm, and were dissociated (Fig. 2B). There were scattered ovoid masses of condensed acidophilic cytoplasm, some with pycnotic nuclear remnants, and sometimes these bodies were present witin hepatocytes or macrophages (Councilman bodies, apoptosis, cytosegregosome formations, Fig. 2A, B). Foci of shrunken hepatocytes were found as well (Coagulative necrosis). There was slight dilation of the space of Disse.

After 2 months: Lamb 10 had extensive formation of large vacuoles in centroazinar hepatocytes, anisocytosis/-nucleosis, scattered swollen and dissociated single hepatocytes, and Councilman bodies (Fig. 3B, C). Some hepatocytes and macrophages contained reddishbrown deposits (HE) which were acid fast, PAS positive, autofluorescent, displayed no activity in polarized light, and contained no iron (ceroid). Biliary hyperplasia, sometimes beyond the terminal plate, and mesenchymal proliferation in portal areas were present (Fig. 3B). Scattered neutrophilic polymorphonuclear cells (PMNs) as well as focal aggregations in the sinusoids, and hypertrophic Kupffer cells (Kc) were seen. Lamb 11 had similar changes, but fatty change was periacinar, and, in addition, proliferation of intralobular biliary cells were seen (Fig. 2D).

After 3 months: Lamb 13 had diffuse fatty change, extensive biliary hyperplasia, proliferation of intralobular biliary cells, and changes as in lamb 10 (Fig. 2E, 3D).

After 5 months: Lamb 16 had diffuse fatty change, ceroid deposits, moderate biliary hyperplasia, lymphocytic infiltration in portal areas, and scattered PMNs in the sinusoids. 
Table 4. Total number of lamb livers $(n=251)$ examined (the material of Table 3 included), numbers which were pale and soft or soft only, numbers with microscopic changes typical $(+)$ or suspect/indicative of OWLD ( \pm ), and ratio of lambs with typical or suspect OWLD histopathology of total number examined.

\begin{tabular}{|c|c|c|c|c|c|c|c|}
\hline \multirow{2}{*}{$\begin{array}{l}\text { Lamb } \\
\text { group }\end{array}$} & \multirow[t]{2}{*}{$\mathrm{n}$} & \multicolumn{2}{|c|}{ Macro } & \multicolumn{2}{|c|}{ Micro } & \multirow[b]{2}{*}{$\begin{array}{l}\text { OWLD }+ \\
\text { OWLD } \pm\end{array}$} & \multirow[b]{2}{*}{$\begin{array}{l}\text { total } \\
\text { number }\end{array}$} \\
\hline & & $\begin{array}{l}\text { Pale/ } \\
\text { soft }\end{array}$ & $\begin{array}{l}\text { Soft } \\
\text { only }\end{array}$ & OWLD + & OWLD \pm & & \\
\hline S & $48^{*}$ & 29 & 4 & 27 & 14 & $41 / 48$ & \\
\hline SCo & 45 & 0 & 7 & 0 & 5 & $5 / 45$ & \\
\hline SCo + & 12 & 0 & 4 & 0 & 0 & $0 / 12$ & \\
\hline $\mathrm{SCoSO}_{4}$ & 8 & 0 & 1 & 0 & 1 & $1 / 8$ & \\
\hline $\mathrm{SB}_{12}$ & 34 & 0 & 2 & 0 & 0 & $0 / 34$ & \\
\hline SCuO & 6 & 6 & 0 & 5 & 0 & $5 / 6$ & \\
\hline SCopell & 8 & 0 & 1 & 0 & 0 & $0 / 8$ & \\
\hline $\mathrm{SCoSeCu}$ & 6 & $1^{* *}$ & 0 & 0 & $1^{* *}$ & $1 / 6$ & \\
\hline SSe & 6 & 1 & 4 & 1 & 3 & $4 / 6$ & \\
\hline SColick & 12 & 0 & 2 & 0 & 2 & $2 / 12$ & \\
\hline H & 44 & 7 & 5 & 0 & 6 & $6 / 44$ & \\
\hline HCo & 6 & 0 & 1 & 0 & 0 & $0 / 6$ & \\
\hline HCopell & 10 & 0 & 0 & 0 & 0 & $0 / 10$ & \\
\hline HColick & 6 & 0 & 1 & 0 & 0 & $0 / 6$ & \\
\hline
\end{tabular}

* Two lambs were killed (1982) before liver changes had developed.

**In this lamb the CoSeCure pellet had been dissolved and absorbed.

In all $S$ lambs, the liver changes were evenly distributed in all sections. All killed $\mathrm{SB}_{12}$ and $H$ lambs had normal livers with intact uniform hepatocytes.

\section{Microscopic criteria for $O W L D$}

Based on the results above, OWLD + comprised: Fatty change (large spherical vacuoles with sharp borders), anisocytosis/-nucleosis, Councilman bodies, coagulative necrosis, ceroid deposits (Fig. 2F), biliary hyperplasia (Fig. 3F), mesenchymal proliferation in portal areas and infiltrations of mononuclear and PMN cells in sinusoids. In OWLD \pm , changes were moderate, unspecific, and important features were lacking, like hepatocyte necrosis or biliary hyperplasia. Fatty change was not present, or only few scattered fat vacuoles could be detected.

\section{Development of changes in other organs}

No specific changes were found by microscopy of rumen, abomasum, duodenum, cae- cum, colon, adrenals, myocardium, kidney, lung and muscles. After 2 months on OWLD pasture, the Peyer's patches (PP) of the ileum of lamb 10 showed lymphocyte depletion and appeared fibrosed, with ceroid deposits in reticuloendothelial cells (RE cells) located towards the periphery. In the $S$ lambs killed after 2 and 3 months respectively on pasture, PP were also moderately fibrotic, but in lamb 16 these changes were pronounced, and RE cells contained ceroid (Fig. 4B, C). The $\mathrm{SB}_{12}$, SCo and $\mathrm{H}$ lambs had normal PP.

In the jejunal lymph nodes (LN), a similar development of changes took place. After 23 months on OWLD pasture, the germinative centres of the $L N$ of lambs 10,11 and 13 appeared hyalinized, and were mostly populated by large cells with enlarged nuclei, some containing ceroid. In the medulla, the RE cells were swollen and contained haemosiderin. The lymph nodes in the $\mathrm{SB}_{12}$, SCo and $H$ lambs were largely normal. 


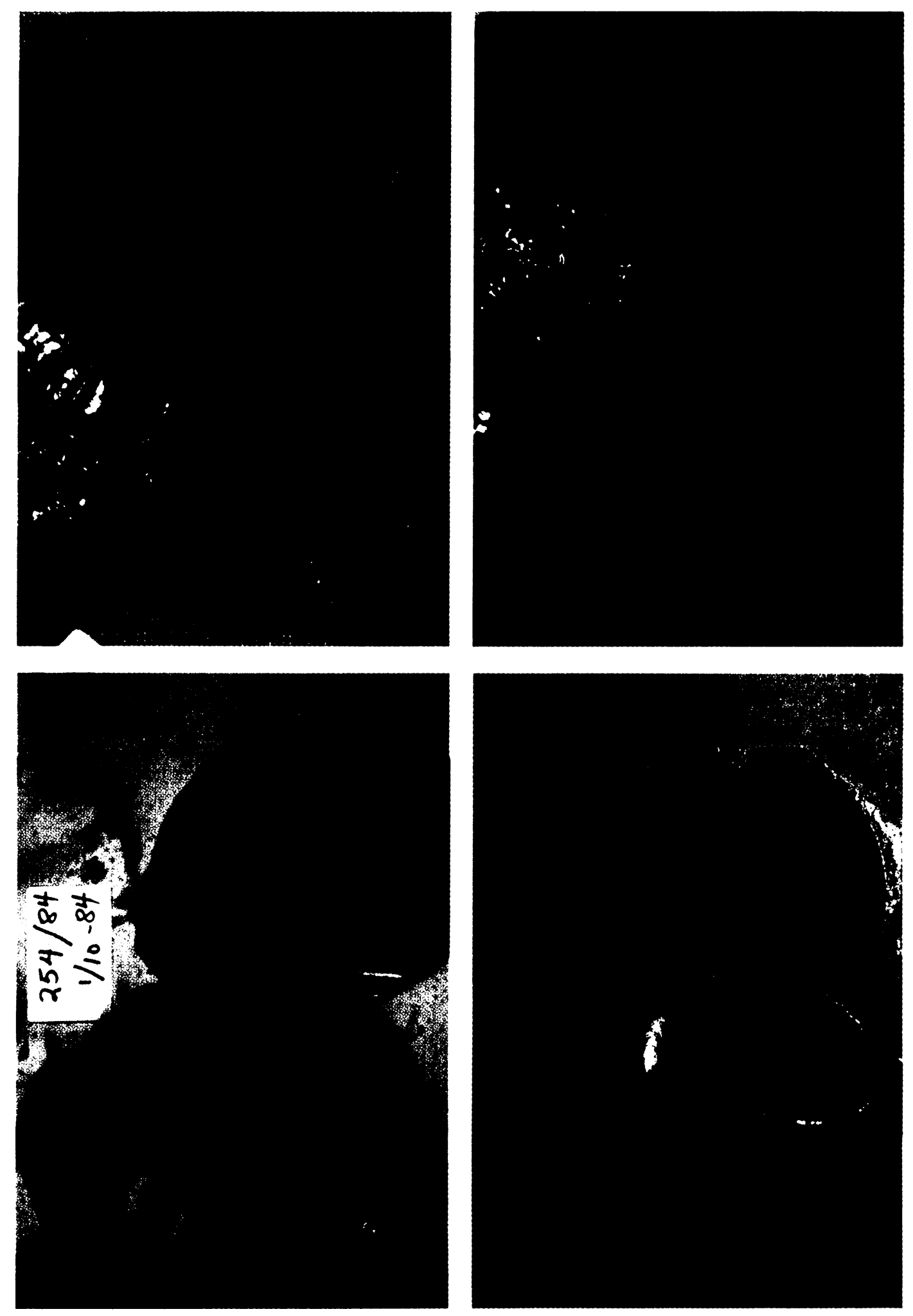

Figure 1. 

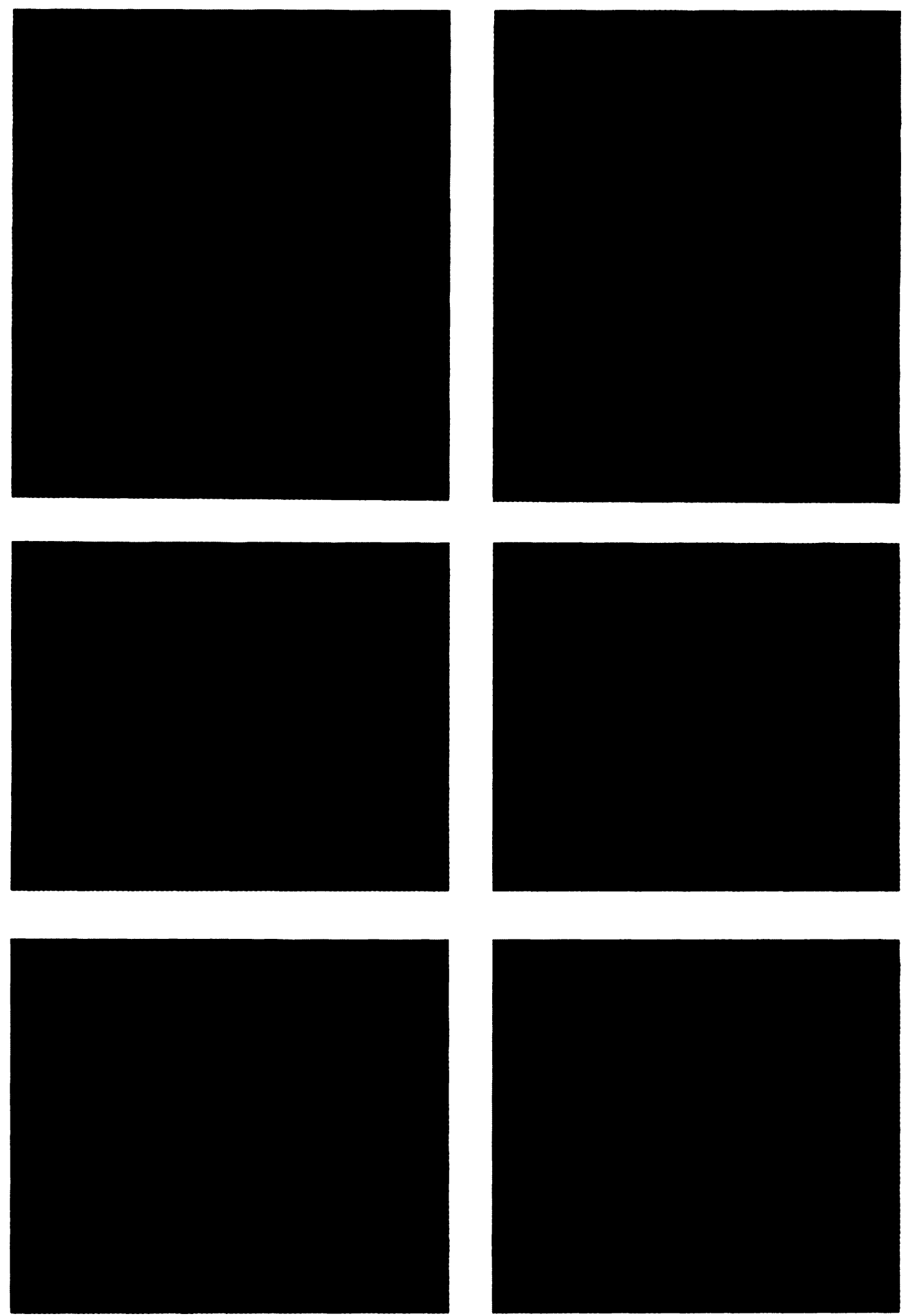

Figure 2. 


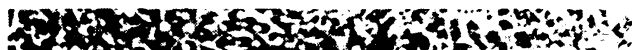

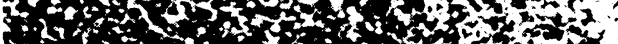

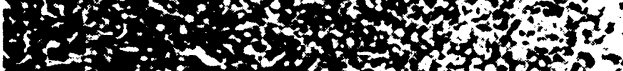

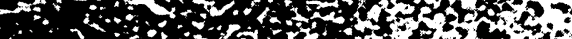
(1)

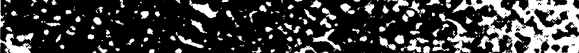

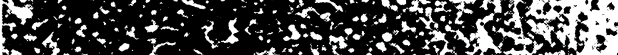

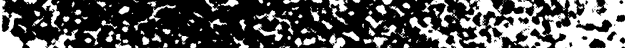

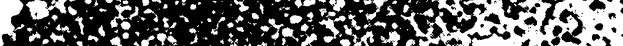

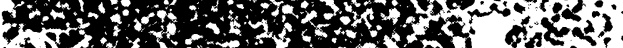

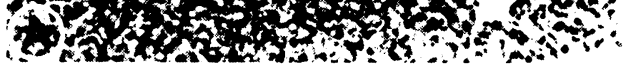

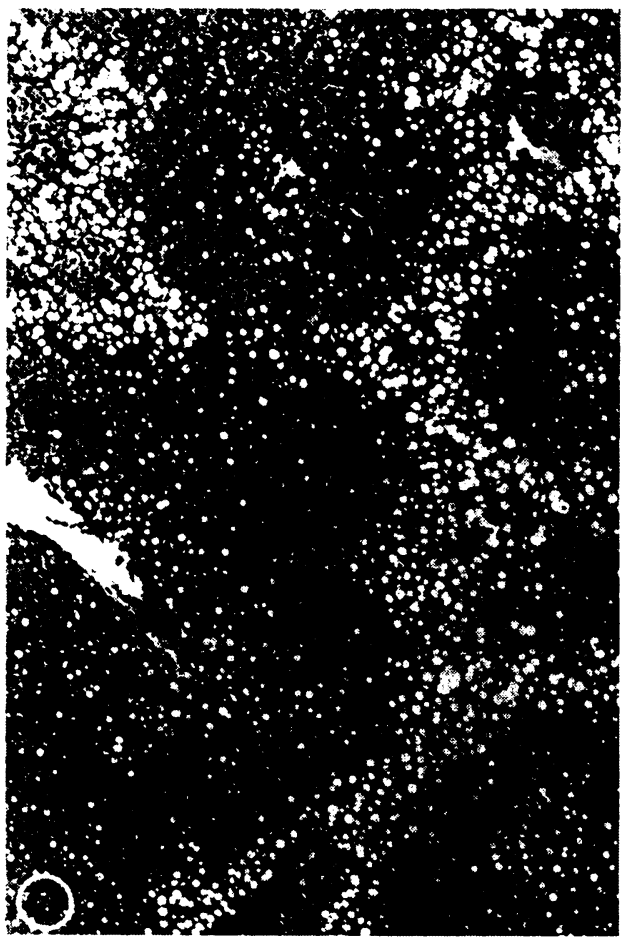

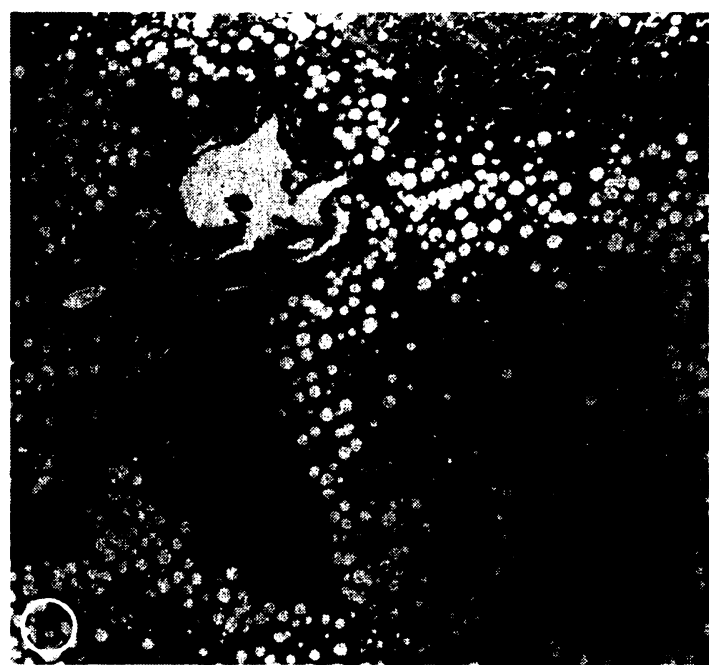

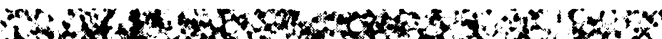

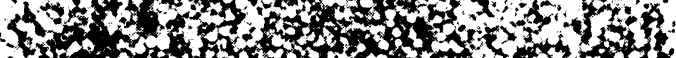

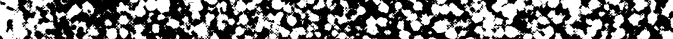

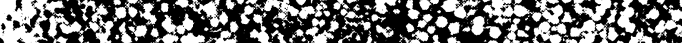

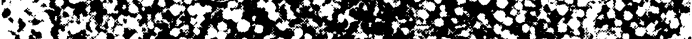

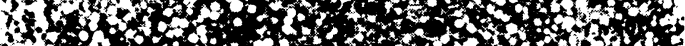

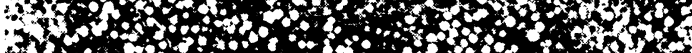

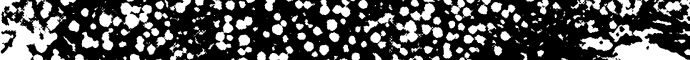

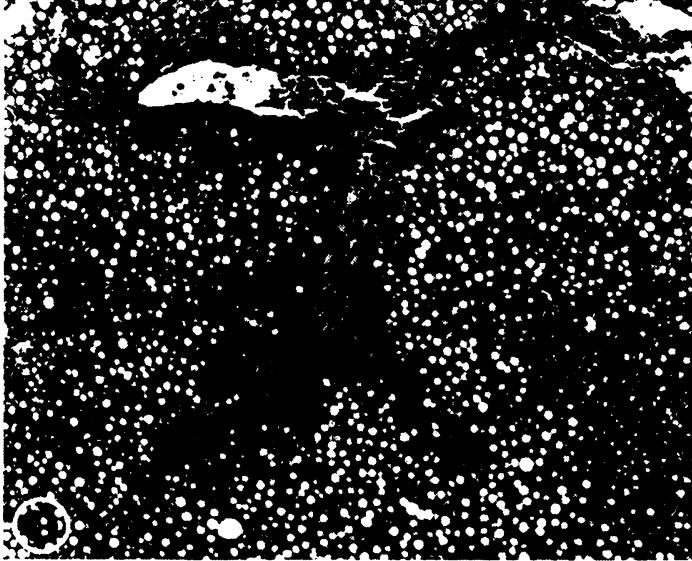
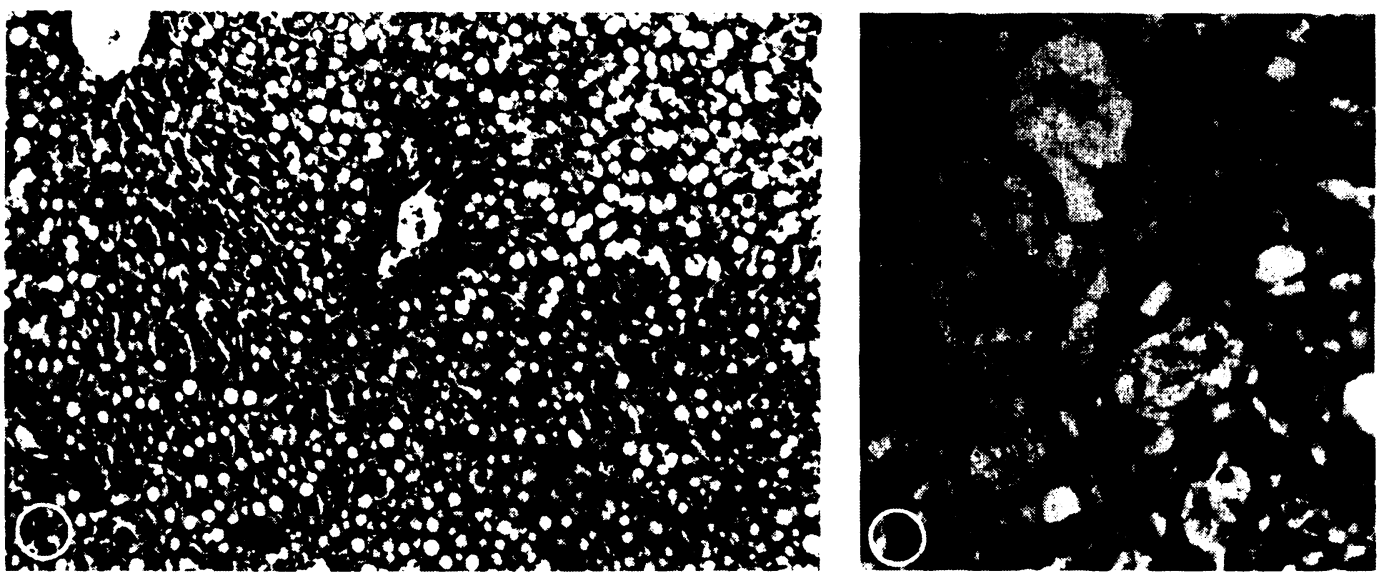
Figure 1. Livers from lambs with ovine white-liver disease (OWLD). The livers were swollen, soft (A) or swollen, pale and soft $(B, C)$. In some the surface had irregular, raised paler areas (D).

Figure 2. Photomicrographs $(\mathrm{HE} \times 400)$ of livers from lambs killed at various intervals throughout grazing, 1982.

A-C: Liver sections from lamb 7 killed after 1 month on OWLD pasture, showing fatty change, Councilman bodies (open arrows), swelling (dark arrows) and anisocytosis/-nucleosis (thin arrows).

D: Liver section from lamb 11 killed after 2 months on OWLD pasture, showing proliferation of intralobular biliary cells.

E: Liver section from lamb 13 killed after 3 months on OWLD pasture, showing accumulation of ceroid in degenerating hepatocyte.

F: Liver section from an OWLD lamb slaughtered after 5 months on pasture (1982), showing ceroid in periacinar hepatocytes and phagocytes.

Figure 3. Photomicrographs of livers from lambs killed at various intervals throughout grazing, 1982.

A: Liver section from lamb 11 killed after 2 months on OWLD pasture, showing fatty change. HE $\times 100$.

B: Liver section from lamb 7 killed after 2 months on OWLD pasture, showing centroacinar fatty change and biliary hyperplasia. $\mathrm{HE} \times 100$.

C: $\quad$ Same as B, $\mathrm{HE} \times 63$.

D: Liver section from lamb 13 killed after 3 months on OWLD pasture, showing diffuse fatty change and proliferation of inflammatory cells in parenchyma and perivascular stroma. HE $\times 63$.

E: Liver section from lamb 16 killed after 5 months on OWLD pasture, showing diffuse fatty change and moderate biliary hyperplasia. $\mathrm{HE} \times 100$.

F: Liver section from an OWLD lamb slaughtered after 5 months on pasture (1982), showing biliary hyperplasia. $\mathrm{HE} \times 400$.
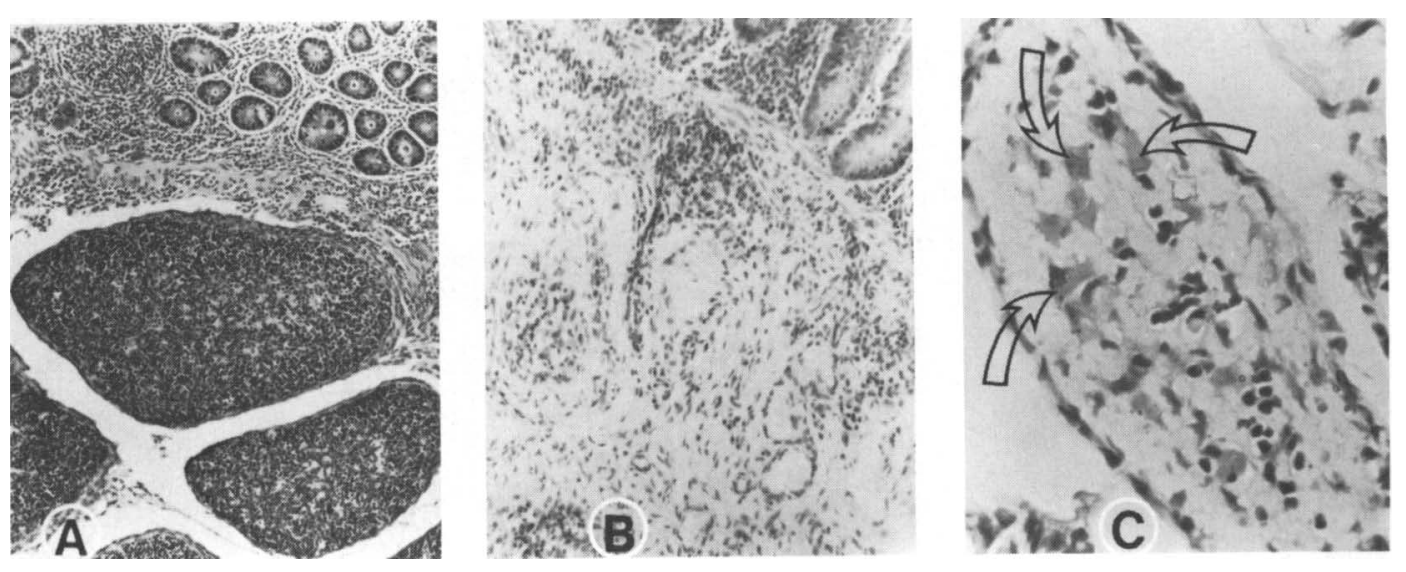

Figure 4.

A: Photomicrograph of ileum from lamb injected every 3 weeks with vitamin $B_{12}$ and slaughtered after 5 months on OWLD pasture, showing normal Peyer's patches (PP). $\mathrm{HE} \times 63$.

B: Photomicrograph of ileum from lamb 16 killed after 5 months on OWLD pasture, showing fibrotic PP with lymphocyte depletion. $\mathrm{HE} \times 63$.

C: $\quad$ Same as B, showing cereoid deposits in reticuloendothelial cells of PP (arrows). HE $\times 400$. 

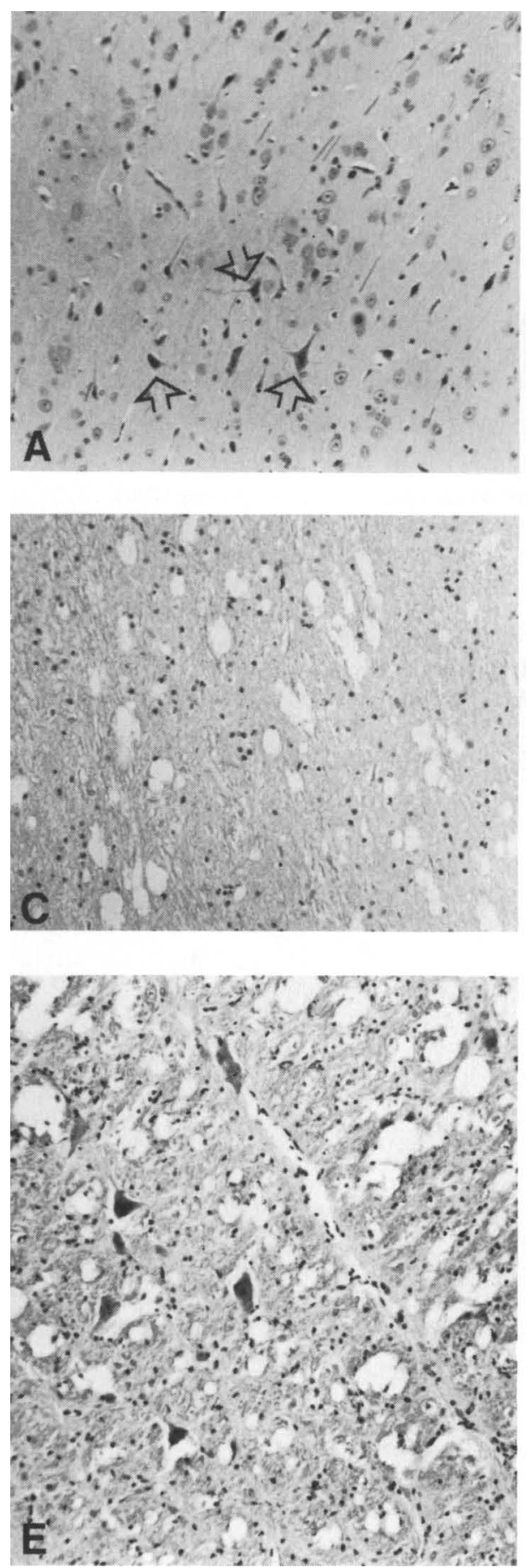
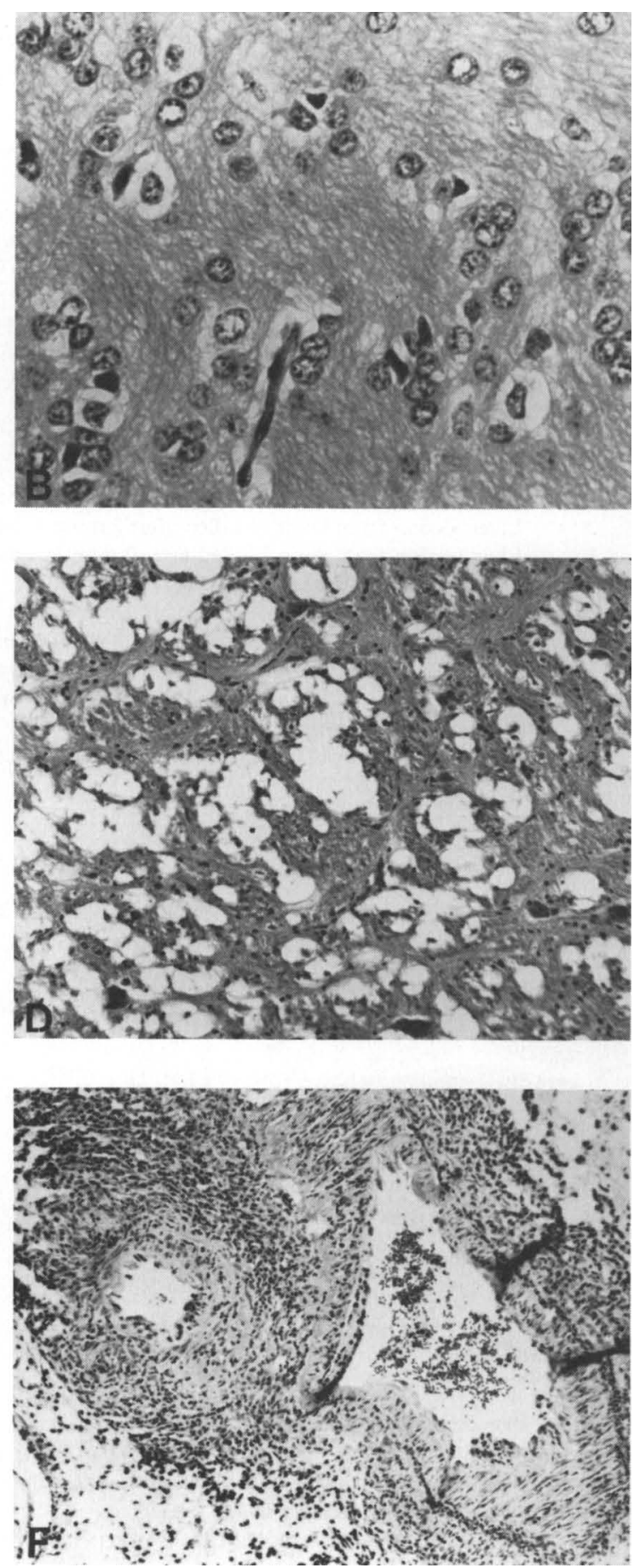

Figure 5. 
In the spleen, increased amounts of haemosiderin was found in the red pulp after 2 months on OWLD pasture, and in all $S$ lambs examined later. In the jejunum of some OWLD lambs, focal areas of epithelial necrosis and hypertrophy, and infiltrations of mononuclear cells were seen.

Microscopy of all brains of OWLD lambs which died or were killed, revealed scattered atrophic and pycnotic neurons (Fig. 5A), as well as an increase of pale swollen astrocytic cells with irregular indented outlines and prominent nucleoli (Alzheimer type II cells, Fig. 5B), especially in the deeper cortex layers and brain stem. There were also patchy areas of microcavitation of white and grey matter in deeper areas of cerebral cortex and throughout the brain stem (Fig. 5, CE).

Two OWLD lambs which were necropsied after 15 and 18 weeks respectively on pasture (1981) had intramural hyalinic necroses of arterioles, endothelial cell hypertrophy, and infiltrations of mononuclear inflammatory cells, sometimes with involvement of PMNs, in the vessel wall. Such vascular changes were found in the myocardium, adrenals, kidneys, lymph nodes, intestinal wall, mesenterium (Fig. 5F), and lung. A moderate polyvasculitis of arterioles in the intestinal wall was seen in an additional 2 OWLD lambs (1981).

\section{Occurrence of microscopic lesions}

All lambs which died or were killed due to OWLD had typical hepatic changes, as well as splenic haemosiderosis. About $70 \%$ had varying degree of sclerotizing of $P P$, and $60 \%$ had similar LN changes. Of the 48 livers examined from $S$ lambs, $56 \%$ were classified as OWLD+, while $83 \%$ either were OWLD + or OWLD \pm (Table 4). All S lambs examined had varying degrees of neuronal atrophy and microcavitations of the brain.

Five out of $6 \mathrm{SCuO}$ lambs had liver changes which could not be discerned from typical OWLD (Table 4). These 5 had sclerotic PP, as well as moderate neuronal atrophy and vacuolizations in the brain.

Only 1 out of 6 SSe lambs was classified as OWLD + . No lambs from any other group had fulminant OWLD. Three and 4 years respectively after Co fertilization of the OWLD pastures, 33 and $50 \%$ of the SCo lambs showed suspect liver histopathology with some few large fat vacuoles in hepatocytes, ceroid deposits, and few Councilman bodies. In the 2 SColick lambs classified as OWLD \pm , scattered large fat vacuoles were found, as well as some Councilman bodies. The $\mathrm{SB}_{12}$ and $\mathrm{SCoSO}_{4}$ lambs had normal livers, except for $1 \mathrm{SCoSO}_{4}$ lambs which was classified as OWLD \pm .

None of the $\mathrm{H}$ lambs had fulminant OWLD, but altogether 6 out of 44 had changes classified as suspect. This ratio was largest in 1986 $(3 / 7)$. General fatty change never occurred.

\section{Blood samples}

All OWLD + lambs had elevated serum GLDH and plasma MMA, together with plasma $B_{12}$ values below $100 \mathrm{pmol} / 1$ (Table 2).

Figure 5.

A-E: Photomicrographs of brain tissue from lambs which died or were killed due to OWLD.

A: Scattered atrophic and pycnotic neurons in cerebral cortex. $\mathrm{HE} \times 100$.

B; Increase of Alzheimer type II astrocytes in mesencephalon. $\mathrm{HE} \times 400$.

C-E: Varying degrees of patchy microcavitation throughout brain stem. $\mathrm{HE} \times 100$.

F: Photomicrograph of vessels of the mesenterium showing vasculitis with infiltrations of inflammatory cells throughout vessel wall. $\mathrm{HE} \times 100$. 


\section{Discussion}

The percentage of pale, soft livers among our S lambs $(69 \%)$ was slightly higher than that found by McLoughlin et al. (1986) in a flock with OWLD (61\%). Sutherland et al. (1979) reported that paleness and softness were typical in the acute phase, but less apparent in the chronic.

\section{Microscopic liver changes}

Details of development of hepatic changes in simple Co deficiency have been difficult to find. The changes found in our lambs with clinical OWLD largely correspond to earlier descriptions (Sutherland et al. 1979, Mitchell et al. 1982). In our case, the fatty change appeared rather suddenly and extensively, and in the centroacinar zone first, while $\mathrm{Su}$ therland et al. (1979) and McLoughlin et al. (1986) reported that it first appeared periacinary. Development of biliary hyperplasia came a few weeks later, as was also noted by Mc Loughlin et al. (1986).

To be able to discriminate between early fatty change and hydropic degeneration, specific fat staining is necessary (Kelly 1985). Due to lack to freeze sectioning facilities, this could not be performed. However, there is little doubt that the distinct vacuoles contained fat. In the severely affected lambs, the liver pieces floated in fixative, the least equivocal evidence of severe fatty change (Kelly 1985).

The fatty change appeared at a time when the lambs grew well (Table 2, Ulvund \& Pestalozzi 1990a). Fatty change as a consequence of starving (Kelly 1985) is therefore excluded. The size and distribution of the vacuoles also differed from what we usually see in late pregnancy, ketosis or lactation, when hepatocytes often contain multiple vacuoles.

Although no morphometric examinations were performed, the appearance of hepato- cytes of very varying size, together with varying size and appearance of the nuclei, led to classification of the changes as anisocytosis/-nucleosis. The eosinophilic structures seen in the hepatocytes were similar to the Councilman bodies described by Wensvoort \& Herweijer (1975) in chronic hepatitis. The structures reflect sublethal hepatocyte injury caused by various insults, and synonymous names may be cytosegregosome formations or acidophilic bodies (Kelly 1985).

There was good correlation between liver changes and live weight (lw) gain. The few S lambs with normal livers at slaughter gained 6 (1981) and $17 \mathrm{~kg}$ (1984) respectively more on pasture than those classified as OWLD + . Generally there was no difference between the $\mathrm{S}$ lambs classified as OWLD+ and OWLD士. The SCuO and SSe lambs with normal livers gained 8 and $2 \mathrm{~kg}$ more than the others within their groups.

The appearance of OWLD suspect changes in SCo lambs three and four years after last Co fertilization correlated with reduced gowth during those years (Ulvund \& Pestalozzi 1990a), as well as reduced plasma $B_{12}$, increased MMA (Ulvund 1990b), and reduced grass Co (Ulund \& Pestalozzi 1990 b).

In the $\mathrm{H}$ lambs the hepatocytes were strikingly better conserved, and extensive fatty change never occurred. The OWLD $\pm \mathrm{H}$ lambs had anisocytosis/-nucleosis, some few large vacuoles in hepatocytes in the periacinar (in 5) or centroacinar zone (in 1) and ceroid deposits in some cells. Only 1 (1983) had a moderate biliary hyperplasia. The findings indicated that the $\mathrm{H}$ lambs lacked the initial trigger which induced the sudden and extensive fatty change in the $\mathrm{S}$ lambs and led to a more serious liver damage.

In the $\mathrm{H}$ lambs there was lack of correlation between OWLD \pm changes and reduced lw gain. In 1985 and 1986, the $\mathrm{H}$ lambs classified as OWLD \pm were among the heaviest 
within the group, and gained on average $7 \mathrm{~kg}$ more on pasture than the others. In 1983, however, the one $\mathrm{H}$ lamb with OWLD \pm was smallest and gained $15 \mathrm{~kg}$ less than the others. It showed no symptoms and was not blood sampled. This was the only $\mathrm{H}$ lamb with a moderate biliary hyperplasia.

Generally, there was good correlation between histopathology and clinical pathology (Ulvund $1990 \mathrm{a}, \mathrm{b}$ ). In all S lambs, fatty change and hepatocyte necrosis were reflected in elevated serum GLDH ( $>15 \mathrm{U} / \mathrm{l})$, and fulminant OWLD was associated with increased plasma MMA ( $>15 \mu \mathrm{mol} / \mathrm{l})$ and lowered plasma $B_{12}(<100 \mathrm{pmol} / \mathrm{l}$, Table 2$)$.

A certain correlation between suspect histopathology and blood chemistry was also seen in the $\mathrm{H}$ lambs. In 1985 , the 2 OWLD $\pm \mathrm{H}$ lambs had plasma $B_{12}$ below $150 \mathrm{pmol} / 1$ throughout grazing, and plasma MMA between 1 and $11 \mu \mathrm{mol} / \mathrm{l}$. From late July, serum GLDH was also highest in these 2 (>15 $\mathrm{U} / \mathrm{l})$. In 1986,2 of the 3 OWLD \pm lambs were blood sampled, and had the lowest plasma $B_{12}(<100 \mathrm{pmol} / \mathrm{l})$ and the highest plasma MMA ( $>15 \mu \mathrm{mol} / \mathrm{l})$ throughout Aug.-Sept., as well as the highest serum GLDH (>70 U/l). The fact that these 5 lambs on average gained $20 \mathrm{~kg}$ more on pasture than the $\mathrm{S}$ lambs strenghtens the hypothesis that they were not exposed to the initial OWLD »trigger mechanism".

On the OWLD pastures, low amount of grass Co seemed to be correlated with seriousness of disease, as the higher content in 1984 (Ulvund \& Pestalozzi 1990a) resulted in better growth and milder hepatic changes seen that year. The fact that $\mathrm{H}$ grass contained less Co than S grass in $1986(0.08 \mathrm{mg} / \mathrm{kg}$ $\mathrm{DM}$ versus 0.12 ), further strenghtens the suspicion that cofactors were present on the $S$ pastures.

As judged from liver $\mathrm{Cu}$, our OWLD lambs were Cu deficient (Ulvund 1990d), but sensi- tive to $\mathrm{Cu}$ dosing (Ulvund 1990c), a fact which indicates that Co deficiency may predispose lambs to $\mathrm{Cu}$ toxicity. In hepatic damage due to pyrrolizidine alkaloids (Seaman 1987) or lupinosis (Gardiner 1966), similar mechanisms operate. Certain structural similarities exist at the cellular level as well. Features like anisocytosis/-nucleosis, fatty change, hepatocyte necrosis, Councilman bodies and bile duct proliferation occur in varying degree in alkaloid poisoning (Bull 1955, Hooper et al. 1974), lupinosis (Warmelo et al. 1970), annual ryegrass toxicity (ARGT), (Berry et al. 1982) and in the prehaemolytic phase in $\mathrm{Cu}$ poisoning of sheep. In $\mathrm{Cu}$ poisoning, the changes are thought to be due to loss of intracellular homeostasis (King \& Bremner 1979). Loss of cell homeostasis could in fact be a common denominator for all these conditions.

Although Se dosing had no significant effect on lw (Ulvund 1990c), it increased liver Co (Ulvund 1990a), and the liver damage was less prominent than in the unsupplemented lambs (Table 4). The number of lambs was, however, too small to draw any conclusion.

\section{Changes in other organs}

Increased splenic haemosiderosis was a feature of our OWLD lambs, and has also been common abroad in lambs with OWLD (Sutherland et al. 1979) or Co deficiency (Filmer 1933).

In this area of Norway, we have had cases of polyvasculitis in lambs (Ulvund et al. 1984). We do not know whether these lambs were $B_{12}$ deficient, and further investigation of this may seem worthwhile. Polyvasculitis of the heart of $B_{12}$ deficient sheep was lately described by Mohammed \& Lamand (1986). In experimental Co deficiency, Mac Pherson et al. (1976) reported vascular lesions in the brains of some sheep, and concluded that the relevance to Co deficiency had to be explored. 
We found cerebrocortical necroses (CCN) in some earlier OWLD cases, but not in this material. In experimental Co deficiency, Mac Pherson et al. (1976) found CCN in some sheep, as did Sutherland et al. (1979) in OWLD lambs that had been blind. Richards \& Harrison (1981) found status spongiosus and neuron necroses in basal cerebrum/cerebellum in $44 \%$ of the OWLD cases, while Mitchell (1979) found necrotic neurons in the cerebral cortex in some. Status spongiosus was also described in a goat with OWLD (Black et al. 1988).

CNS changes similar to the ones reported in our OWLD lambs were also found by Fell (1981) and Fell et al. (1985) in Co deficiency. Spongy change and development of Alzheimer type II cells have been typical for hepatocerebral disease in man, and in Wilsons disease due to abnormal $\mathrm{Cu}$ metabolism, and such changes in sheep may be an analogue (Fell 1981). In sheep injected with alkaloids, vacuolization of the brain stem showed a positive correlation with amounts of blood ammonia (Hooper et al. 1974). Brain vacuolization has also been found in sheep with lupinosis (Allan \& Nottle 1979), Cu poisoning (Doherty et al. 1969), or ARGT (Berry et al. 1980).

OWLD grass contained more $\mathrm{Al}$ than $\mathrm{H}$ grass (Ulvund \& Pestalozzi 1990b). Al dosing in rabbits have resulted in fatty change and hepatocyte necrosis, pigment deposits in the spleen, and lymphocyte depletion and fibrosis of the splenic pulp (Seibert \& Wells 1929). Al dosing of $B_{12}$ deficient lambs might be performed, to explore whether $\mathrm{Al}$ could have some significance in the OWLD condition.

The changes seen in PP and LN have not been described by others in OWLD. It is difficult to tell whether these are due to lack of $B_{12}$, or to starvation. The changes may be associated with the decreased resistance to- wards parasites and possibly other agents (Ulvund \& Pestalozzi 1990a).

The present investigation supports the view that OWLD is a manifestation of $\mathbf{B}_{12}$ deficiency, but that cofactors act at the cellular level triggering early hepatic fatty change leading to a sequelae of changes resulting in loss of cell homeostasis.

\section{References}

Allen JG, Nottle FK: Spongy transformation of the brain in sheep with lupinosis. Vet. Rec. 1979, 104, 31-33.

Berry PH, Howell JMcC, Cook RD: Morphological changes in the central nervous system of sheep affected with experimental annual ryegrass ( $\mathrm{LO}$ lium rigidum) toxicity. J. comp. Path. 1980, 90, 603-617.

Berry PH, Richards RB, Howell JMcC, Cook RD: Hepatic damage in sheep fed annual ryegrass, Lolium rigidum, parasitised by Anguina agrostis and Corynebacterium rathayi. Res. Vet. Sci. 1982, 32, 148-156.

Black $H$, Hutton JB, Sutherland RJ, James MP: White liver disease in goats. N. Z. vet. J. 1988, 36, 15-17.

Bull LB: The histological evidence of liver damage from pyrrolizidine alkaloids. Megalocytosis of the liver cells and inclusion globules. Aust. vet. J. 1955, 31, 33-40.

Carson FL, Martin J, Lynn JA: Formalin fixation for electron microscopy: A re-evaluation. Amer. J. clin. Path. 1973, 59, 365-373.

Culling CFA: Handbook of Histopathological Techniques. 2nd. ed. Butterworth, London 1963.

Doherty PC, Barlow RM, Angus KW: Spongy changes in the brains of sheep poisoned by excess dietary copper. Res. Vet. Sci. 1969, 10, 303-305.

Fell BF: Pathological consequences of copper deficiency and cobalt deficiency. Phil. Trans. B, 1971, 294, 153-169.

Fell BF, Hesketh JE, Lough AK, Duncan WRH, Mackie WS: Observations on the central nervous system of sheep deficient in cobalt (Vitamin $B_{12}$ ). In: Mills CF, Bremner I, Chesters JK (eds): Trace elements in Man and Animals, TEMA-5. Proc. 5th. Int. Symp. on Trace Elements in Man and 
Animals, Aberdeen 1984. CAB, London 1985, p. 263-265.

Filmer JF: Enzootic marasmus of cattle and sheep. Aust. vet. J. 1933, 9, 163-179.

Garton GA, Duncan WRH, Fell BF: Aspects of cobalt deficiency in ewes and their lambs. In: Gawthorne JM, Howell JMcC, White 1 (eds.): Trace Element Metabolism in Man and Animals. Springer Verlag, Berlin 1982, p. 382-384.

Gardiner MR: Mineral metabolism in sheep lupinosis. J. comp. Path. 1966, 76, 107-120.

Hooper PT, Best SM, Murray DR: Hyperammonaemia and spongy degeneration of the brain in sheep affected with hepatic necrosis. Res. Vet. Sci., 1974, 16, 216-222.

Kelly WR: The liver and biliary sysem. In: Jubb KVF, Kennedy PC, Palmer N: (eds.): Pathology of Domestic Animals, 3rd. ed., vol. 2, Academic Press, London 1985, p. 239-312.

King TP, Bremner I: Autophagy and apoptosis in the liver during the prehaemolytic phase of chronic copper poisoning in sheep. J. comp. Path. 1979, 89, 515-530.

MacPherson A, Moon FE, Voss RC: Biochemical aspects of cobalt deficiency in sheep with special reference to vitamin status and a possible involvement in the aetiology of cerebral necrosis. Brit. vet. J. 1976, 132, 294-308.

McLoughlin M, Rice DA, McMurray CH, Blanchflower WJ, Goodall $E$ : Hepatic lesions associated with vitamin $\mathbf{B}_{12}$ deficiency in weaned lambs. Proc. 6th Int. Conf. on Production Disease in Farm Animals, Belfast 1986, p. 104-107.

Mitchell PJ: Studies on ovine white liver disease in East Gippsland. Victorian vet. Proc. 1979, 37, 30.

Mitchell PJ, McOrist S, Thomas $K \boldsymbol{W}$, McCausland $P$ : White liver disease of sheep. Aust. vet. J. 1982, 58, 181-184.

Mohammed $R$, Lamand $M$ : Cardiovascular lesions in cobalt-vitamin $B_{12}$ deficient sheep. Ann. Rech. Vet. 1986, 17, 447-450.

Richards RB, Harrison MR: White liver disease in lambs. Aust. vet. J. 1981, 57, 565-568.

Seaman JT: Pyrrolizidine alkaloid poisoning of sheep in New South Wales. Aust. vet. J. 1987, 64, 164-167.
Seibert FB, Wells $G H$ : The effect of aluminum on mammalian blood and tissues. Arch. Path., 1929, 8, 230-262.

Surtherland RJ, Cordes DO, Carthew GC: Ovine white liver disease - an hepatic dysfunction associated with vitamin $B_{12}$ deficiency. $N$. Z . vet. J. 1979, 27, 227-232.

Ulvund MJ: Ovine white-liver disease (OWLD). Vitamin $B_{12}$ and methyl malonic acid (MMA) estimations in blood. Acta vet. scand. 1990b, 31, 267-275.

Ulvund MJ: Ovine white-liver disease (OWLD). Serum copper and effects of copper and selenium supplementation. Acta vet. scand. 1990c, 31, 287-295.

Ulvund MJ: Ovine white-liver disease (OWLD). Trace elements in liver. Acta vet. scand. 1990d, 31, 297-307.

Ulvund MJ, Pestalozzi M: Ovine white-liver disease (OWLD) in Norway. Clinical symptoms and preventive measures. Acta vet. scand. 1990a, 31, 5362.

Ulvund MJ, Pestalozzi M: Ovine white-liver disease (OWLD). Botanical and chemical composition of pasture grass. Acta vet. scand. 1990b, 31, 257 265.

Ulvund $M J$, overàs $J$ : Chronic hepatitis in lambs, a condition resembling ovine white liver disease in New Zealand. N. Z. vet. J. 1980, 28, 19.

Ulvund MJ, Overds $J$, Waldeland $H$ : Polyvasculitis in lambs from the South-Western part of Norway. A short survey of clinical symptoms, hematology and pathology. Proceedings Joint Veterinary Pathology Meeting, Utrecht 1984, p. 63.

Warmelo KT van, Marasas WFO, Adelaar TF, Kellerman TS, Rensburg IBJ van, Minne JA: Experimental evidence that lupinosis of sheep is a mycotoxicosis caused by the fungus Phomopsis leptostromiformis (Kâhn) Bubàk. J. S. Afr. vet. med. Ass. 1970, 41, 235-247.

Wensvoort $P$, Herweijer $\mathrm{CH}$ : Chronische hepatitis by lammern (Chronic hepatitis in lambs). Tijdschr. Diergeneesk., 1975, 100, 221-228. 


\section{Sammendrag}

Kvitleversjuke (kobolt/vitamin $B_{12}$ mangel) hos lam. Patologi.

Mikroskopiske leverforandringer ble tidligst funnet etter 1 mảned på sjukdomsbeitet, og omfattet utbredt fettinfiltrasjon $i$ form av store vakuoler $i$ levercellene, anisocytose/-nucleose og dannelse av Councilman-legemer. Senere kom ceroidavleiring, gallegangshyperplasi, Kupffercellehypertrofi, og infiltrasjon av betennelsesceller.

Totalt $83 \%$ av alle undersøkte lam som gikk pá sjukdomsbeitene hadde typiske eller suspekte leverforandringer. Økt hemosiderinavleiring i milten var vanlig. Hos alvorlig affiserte dyr var det en viss lymfocyttuttømning og fibrose i de germinative sentra $i$ peyerplettene i tarmen og i tarmlymfeknutene, samt neuronal atrofi og mikroaviteringer i hjernestammen. Fire hadde polyvasculitt.

Kobolt/vitamin $B_{12}$ doserte lam viste ingen spesifikke forandringer.

Lam som gikk pá andre beiter ( $\mathrm{H}$ lam), og som noen ár var subklinisk $\mathrm{Co} / \mathrm{B}_{12}$ deficitte, viste ingen fulminante OWLD forandringer. Et år hadde 3 av 7 lam moderate forandringer suspekte for OWLD, men uten særlig fettinfiltrasjon. Resultatene viser at OWLD er en vitamin $B_{12}$ mangel intensivert av samvirkende faktorer som forårsaker fettavleiring i levercellene og større leverskade, som resulterer $i$ at den intracellulære homeostasen ødelegges og levercellene blir mer sårbare for f.eks. kopper.

(Received October 12, 1989; accepted January 17, 1990).

Reprints may be requested from: Martha J. Ulvund, State Veterinary Research Station for Small Ruminants, P. O. Box 264, N-4301 Sandnes, Norway. 